\title{
Chronic inflammatory response modulation against Leishmania (L.) amazonensis by homeopathic thymulin and antimonium crudum in balb/c mice
}

\author{
Fabiana Rodrigues Santana ${ }^{1}$, Thayná Neves Cardoso ${ }^{1}$, \\ Cideli de Paula Coelho' ${ }^{1}$ Lika Osugui ${ }^{3}$, Marcia Dalastra Laurenti ${ }^{4}$, \\ Elizabeth Perez Hurtado ${ }^{1,3}$, Leoni Villano Bonamin 1,2 \\ 1 Paulista University(UNIP), São Paulo, Brazil \\ ${ }^{2}$ University of Santo Amaro (UNISA), São Paulo, Brazil \\ ${ }^{3}$ Federal University of Sao Paulo (UNIFESP), São Paulo, Brazil \\ ${ }^{4}$ University of São Paulo School of Medicine (FMUSP), São Paulo, Brazil
}

\begin{abstract}
In previous studies it was found that thymulin $5 \mathrm{cH}$ (thymic hormone) can modulate immune processes in several diseases. Additionally, the Antimonium crudum has used in dogs bearing leishmaniosis, according to the similia principle. We studied the inflammatory and immune modulation by thymulin $5 \mathrm{CH}$ and Antimonium crudum $30 \mathrm{CH}$ treatment in mice experimentally inoculated with Leishmania (L.) amazonensis. Male adult Balb/c mice were inoculated with Leishmania $\left(2 \times 10^{5}\right.$ promastigotes) into the footpad to induce inflammatory response and peritoneum and spleen cells were evaluated by flow cytometry after 60 days. Animals were divided in 3 groups $(\mathrm{n}=10)$ : thymulin $5 \mathrm{cH}$, Antimonium crudum $30 \mathrm{cH}$ and vehicle /control. Treatment was made in blind, daily, in water/alcohol 30\% diluted 1:2500 in drinking water, during all experimental period. CD11b (activated phagocytes and B1 cells), CD19 (B1 cells and B2), CD4 and CD8 (effective T lymphocytes) markers were used to identify immune cells subsets in peritoneal washing fluid and spleen cell suspension. Mice treated with thymulin $5 \mathrm{cH}$ presented increase in peritoneal and spleen B1 stem cells $\left(\mathrm{X}^{2}=0.0001\right)$ and higher $\mathrm{CD} 8+/ \mathrm{CD} 4+$ ratio in spleen, regarding to the control. Also, Antimonium crudum $30 \mathrm{CH}$ induced a mild increase in $\mathrm{B} 1$ cells in peritoneum and spleen ( both $\mathrm{X}^{2}, \mathrm{p}=0.0001$ ). Further histological analysis of the primary lesion will be done in the next step, to elucidate the impact of these findings in the disease evolution. The results show that both treatments stimulate B1 stem cell proliferation and suggest the cooperation of $\mathrm{T}$ spleen lymphocytes in the process.
\end{abstract}

Keywords: leishmania, thymulin, antimonium crudum, mice

\section{(c)) BY-NC-ND Licensed to GIRI}

Support: FAPESP 2010/50842-0

Conflict of interest: authors declare there is no conflict of interest

Received: 01 June 2012; Revised: 08 August 2012; Published: 30 September 2012.

Correspondence author: Leoni Villano Bonamin, leonibonamin@gmail.com

How to cite this article: Santana FR, Cardoso TN, Coelho CP, Osugui L, Laurenti MD, Hurtado ECP, Bonamin LV. Chronic inflammatory response modulation against Leishmania (L.) amazonensis by homeopathic thymulin and antimonium crudum in balb/c mice. Int J High Dilution Res [online]. 2012 [cited YYYY Month dd]; 11(40):163-163. Proceedings of the XXVI GIRI Symposium; 2012 Sep 20-22; Florence (Italy). GIRI; 2012; Available from: http://www.feg.unesp.br/ ojs/index.php/ijhdr/article/view/581/579 